http://dx.doi.org/10.12775/szhf.2014.036

\title{
Adam Fedyniuk \\ Ogólny schemat przyczynowej teorii manipulacji według Jamesa Woodwarda
}

Zjawisko manipulacji w czasach współczesnych stało się tematem licznych dyskusji. Najogólniej ujmując, ich uczestnicy podzielili się na dwa obozy: zwolenników uznających to zjawisko za bardzo złożone i wymagające skrupulatnej analizy oraz przeciwników, którzy starają się zredukować struktury logiczne wszelkich form manipulacji do modeli błędnych kół, samo zaś zjawisko za przypadkowe i mające swe podłoże w ułomnościach ludzkiej psychiki.

Nie można zaprzeczyć, że zwolennicy teorii manipulacji uznają redukcję za niewystarczające wyjaśnienie działania wytwarzających to zjawisko mechanizmów. James Woodward, odwołując się do modelu przyczynowego, przyjmuje w tym względzie za Garym Orcuttem, następującą definicję:

[...] $Z_{1}$ jest przyczyną $Z_{2}$ jest wygodnym sposobem stwierdzenia, że jeśli wybierze się działanie, które kontroluje $Z_{1}$, otrzyma się działanie, które kontroluje także $\mathrm{Z}_{2}{ }^{1}$.

Z powyższego fragmentu wynika, że manipulacja będąca swoistą akcją w jakiś sposób wpływającą na stan danej przyczyny, w zależności od tego

\footnotetext{
${ }^{1}$ J. Woodward, Making things happen, Oxford University Press, New York 2003, s. 26.
} 
czym jest dana akcja, ma możliwość zmiany stanu skutku. Posiadając wiedzę na temat tego typu zależności, można także przewidzieć zmiany, jakie w ich efekcie nastąpią, a nawet odpowiednio nimi pokierować.

Kolejnym ważnym aspektem manipulacji pozostaje kwestia wolnej woli. W naukach empirycznych eksperymentowanie uzależnione jest od przyjęcia przesłanki, w której zakłada się, że posiadamy wolną wolę i działając wedle niej jesteśmy w stanie dokonywać eksperymentów, działać, a następnie obserwować skutki owych działań. W trakcie podejmowania tak rozumianych eksperymentów niejako nie możemy być z założenia w żaden sposób zmanipulowani, co znaczy, że nie mogą wpływać na nas żadne zewnętrzne bodźce, które mogłyby stać się źródłem zakłócenia „wolności eksperymentowania”. Brak wyabstrahowania z rzeczywistości powinien w takim wypadku tworzyć pewne ukryte parametry, które by tę wolność ograniczały, by nie powiedzieć: znosiły. Przyjęcie, że pozostajemy ciągle pod wpływem jakiejś formy manipulacji doprowadza nas do martwego punktu. Pojawia się wówczas pragnienie - będące w istocie pułapką myślową - do uznania każdego działania lub przedmiotu za jedynie element większej, samonapędzającej się struktury o niedefiniowalnym modelu funkcjonowania. A z pułapki takiej nie ma wyjścia. Podział zależności na zależności przyczynowe oraz na korelacje pozostające poza schematem „przyczyna - skutek” pozwalają na dostrzeżenie subtelnych różnic sprawiających, że analiza zjawiska manipulacji staje się znacznie bardziej wnikliwa.

W naukach, gdzie praktyka jest ważnym elementem dociekań, opisywane tu zjawisko manipulacji jest dostrzegalne najlepiej. Można powiedzieć, że przedstawiciele takich dyscyplin najlepiej dostrzegają mechanizmy, a istotną przyczyną takiego stanu rzeczy stają się czynniki praktyczne. Ważność doświadczeń empirycznych stanowi swoistą przeciwwagę dla teoretyków, którzy w tej perspektywie zawsze są gotowi do odrzucenia, pod wpływem doświadczeń, interpretacji zjawisk. Z drugiej zaś strony, to właśnie teoretyzowanie otwiera przed nimi szersze pole dociekań aniżeli empiryczność stawiająca nas przed faktami dokonanymi i łącząca się z wrażeniem, że w wyniku pozoru zmysłowego staliśmy się ofiarą pewnego rodzaju manipulacji. Możliwość stania się ofiarą takiej manipulacji sprawia, że praktycy nauk empirycznych korzystają z wielu konstruktów teoretycznych opisujących wszelkie zmiany parametrów i skutki, które takowe zmiany za sobą pociągają. Niezręczne sformułowanie; proponuję: Przyjmuje się zatem, że istnieje pewna forma uobecniania się manipulacji, w której nie chodzi o instrumentalizację pewnych dokonanych przez nasz umysł korelacji. 
Predyspozycja do rozróżnienia związków przyczynowych oraz nieprzyczynowych zauważalna jest już u niemowląt. Wedle badań ${ }^{2}$ przeprowadzonych w 1987 roku szybciej adaptowały się one do naturalnych zachowań przedmiotów wskazujących na związek przyczynowo-skutkowy aniżeli do zachowań na taki związek nie wskazujących. Wykazanie naturalnej dążności ludzkiego umysłu do odkrywania struktur logicznych w otaczającym go świecie jest przy budowaniu teorii manipulacji elementem kluczowym. Nie znaczy to oczywiście, że sam świat ma strukturę logiczną rodem, powiedzmy z Tractatus logico-philosophicus Wittgensteina, lecz ludzki umysł potrafi tłumaczyć pewne zjawiska przez pryzmat logiki.

Chcąc zbudować prymitywny model manipulacji i mając przy tym na względzie przewidywanie skutków przy zmianie parametrów przyczyn, należy pamiętać o tej logicznej stronie ludzkiego umysłu. To właśnie dzięki owym samorzutnym reakcjom na konkretne warunki jesteśmy w stanie określać, jak obiekt manipulujący się zachowa. Trzeba przy tym zaznaczyć, że prostota aplikowanego modelu jest bezpośrednią przyczyną ograniczenia zmian zachodzących w skutkach. Im prostszy i ogólniejszy jest model, tym ogólniejsze będą rezultaty manipulacji. Podobnie im model jest bardziej skomplikowany, tym większa będzie dokładność przewidywania skutków. Oddziaływanie modelu można tu porównać do eksperymentu, w którym im lepiej odizolowane są bodźce zewnętrzne i im więcej sił wewnątrz układu podlega kontroli, tym preferowany skutek staje się dokładniejszy i łatwiejszy do osiągnięcia. Takie spojrzenie na zjawisko manipulacji daje przejrzysty obraz aplikacji praktycznej: tworząc pewien zbiór parametrów podpadających pod pewien obiekt A, który powoduje $\mathrm{B}$, jesteśmy w stanie zwiększyć nasze szanse na osiągnięcie wyznaczonego celu.

W najogólniejszym sensie, celem wiedzy przyczynowej jest przewidywać. Tworzenie dystynkcji między związkami przyczynowymi a korelatami innego rodzaju komplikuje zaś proces przewidywania. Istnieje bowiem wiele związków zachodzących między różnymi zjawiskami, które zakłócają wewnętrzną spójność modeli. Przykładem mogą tu być choćby ślady stóp na plaży, które ewidentnie pozwalają przyjąć, że ktoś tędy przechodził, lecz wiedząc, że jakaś osoba szła kiedyś po plaży, nie dysponuje się przecież żadną informacją na temat ewentualnego istnienia śladów na piasku.

\footnotetext{
2 Tamże, s. 29.
} 
Wywieranie wpływu i poprawna argumentacja.

Formułowanie zdań

obarczonych automatycznie wychwytywanym kontekstem

W kwestii wywierania wpływu na innych ważną rolę odgrywa umiejętność właściwego formułowania wypowiedzi. Nie ogranicza się ona bynajmniej do samego tylko konstruowania zdań poprawnych gramatycznie, wykorzystujących ściśle zdefiniowane pojęcia, a nawet estetycznie zadowalających. Istnieje pogląd, że właściwie wszystkie wypowiedzi są obarczone pewną formą argumentacji. Ten ostatni element jest kluczowy, by mechanizm wywierania wpływu na drugą osobę mógł skutecznie działać. Sylogistyka, czyli nauka zajmująca się argumentacją, jest jedną z najstarszych dziedzin wiedzy, jej początki sięgają czasów Arystotelesa. Można przyjąć, że sprawa wywierania komunikacyjnego wpływu na drugiego człowieka i najróżniejsze formy perswazji towarzyszą ludziom właściwie od zarania dziejów.

Arystoteles wprowadził podział na argumenty dedukcyjne i indukcyjne. Argumenty dedukcyjne oparte są na prawach ogólnych i czynią wniosek koniecznym logicznie, natomiast indukcyjne sprawiają, że wniosek uzyskuje pewien stopień prawdopodobieństwa. Im więcej we wnioskowaniu indukcyjnym znajduje się reprezentatywnych argumentów, tym większe będzie prawdopodobieństwo, że sam wniosek jest poprawny. Inny podział argumentów przedstawianych przez Arystotelesa dzieli je na dające możliwość dojścia do wiedzy obiektywnie pewnej, czyli mogące wyprowadzić powszechnie uznane wnioski, oraz na takie, którym przysługuje charakter czysto retoryczny, pozwalający na przekonanie konkretnej grupy słuchaczy.

Powyższe podziały wchodzą w skład argumentacji merytorycznej. Dają one możliwość przejrzystego kreowania wypowiedzi charakteryzującej się argumentami rzeczowymi. Mimo to, Arystoteles był świadomy istnienia form perswazji nieargumentacyjnej. Formuły te, czyli metody zwane ethos i pathos, służą wzmacnianiu siły argumentów przez podnoszenie wiarygodności wypowiedzi oraz sterowanie nastrojami odbiorców. Wymienione dwie metody stanowią fundament, na którym można budować różne rodzaje chwytów retorycznych (topoi) wzmacniających perswazyjny charakter wypowiedzi. W średniowieczu próbowano nawet stworzyć listę tego typu zabiegów, lecz nie była ona przejrzysta i od strony formalnej wprowadzała jedynie nowe nieścisłości. 
Zdaniem Arystotelesa wewnętrzna struktura argumentu była sylogizmem, czyli składała się z tzw. przesłanki mniejszej, większej oraz wniosku³. Taka jej postać jest po dziś dzień aktualna i wykorzystuje się ją we współczesnej argumentacji. Jednakże w ogólnej perspektywie rozwój wymienionych dziedzin oddzielił od siebie teorię dowodu, inaczej mówiąc logikę od sztuki przekonywania i poprawnego przedstawiania swoich racji, które to dziedziny w starożytności zawierały się w dialektyce, czyli sztuce prowadzenia sporów.

Można $\mathrm{z}$ łatwością zauważyć, że model przedstawionego tu sylogizmu, jeśli chcemy dopasować go do sytuacji korzystania $z$ argumentacji potocznej, ze względu na swoją prostotę wymaga pewnego dookreślenia. Analizując argumenty przynależne do różnorodnych wypowiedzi, musimy wziąć pod uwagę wiele ich aspektów. Na przykład: nie wszystkie wypowiedzi potoczne otwarcie stwierdzają fakty, gdyż dzięki elastyczności budowy zdań istnieje czasem możliwość zawierania się w nich różnych informacji ukrytych. W języku potocznym nie musimy za każdym razem rozpoczynać zdania słowami: albowiem, ponieważ, gdyż, skoro, by zaznaczyć, że w tym konkretnym momencie przedstawimy dany argument. $Z$ tego powodu zdania mogą zawierać komponenty niejawne, czyli właśnie ukryte elementy wypowiedzi, których odkrycie pozostawia się możliwościom percepcyjnym odbiorcy.

Analizując argumentację w poszukiwaniu przesłanek ukrytych, otrzymamy niewątpliwie ich pokaźny zbiór. Wyzwaniem dla ludzkiego intelektu jest wybranie tych, które na pewno są w wypowiedzi stwierdzane niejawnie. Dwa kryteria takiego wyboru przedstawione przez Marka Tokarza to: niezbędność dla poprawności argumentacji oraz możliwość wysondowania z kontekstu, że nadawca wierzy w prawdziwość zdania oraz oczekuje takiej samej wiary od odbiorcy. Oczywiście w sytuacji, gdy nadawcą jest manipulator, właściwa ocena tego drugiego kryterium będzie o wiele trudniejsza. Za pomocą reguł perswazji nieargumentacyjnej zyskujemy jednak możliwość zawoalowania prawdziwego kontekstu bądź też jego modyfikacji w sposób pozwalający na przyjęcie go w sytuacji, w której w rzeczywistości nie byłby on zadowalający.

Zachowanie formalnej poprawności we wszystkich argumentacjach jest jednak niemożliwe. Uznanie danej wypowiedzi za dostatecznie przekonującą jest zawsze kwestią bardzo niejasną. Pomimo wzniosłego dążenia do pełnej dokładności i jasności wypowiedzi, jako cechy bezwarunkowe wciąż pozo-

\footnotetext{
${ }^{3}$ Arystoteles, Organon III - Prior Analytics, [w:] Aristotle - Works, red. W. D. Ross, Constitution Society, s. $81 \mathrm{URL}=<$ http://www.constitution.org/ari/aristotle-organon+physics.pdf $>$
} 
stają one w praktyce. Jedną z metod oddzielania wartościowych przesłanek od zbędnych jest stosowanie tzw. brzytwy ekonomicznej. Jej definicja brzmi:

Poprawna argumentacja jest nieekonomiczna, jeśli użyto w niej takiej przesłanki, której usunięcie nie wywołałoby najmniejszej nawet zmiany w stopniu uzasadnienia konkluzji; poprawna argumentacja jest ekonomiczna, gdy wszystkie użyte $\mathrm{w}$ niej przesłanki są niezbędne do uzasadnienia konkluzji z danym stopniem pewności ${ }^{4}$.

Celowe dodawanie do argumentacji zbędnych przesłanek czasem bywa zabiegiem maskującym jej niepoprawność. Przesłanki takie mogą zawierać się $\mathrm{w}$ formach wypowiedzi bogatych w różnorakie zabiegi stylistyczne, ozdobniki tekstu itp., angażujące mechanizmy typu ethos i pathos. W efekcie nawarstwianie się skomplikowanych struktur wypowiedzi może tworzyć swoistą, sieć w której odbiorca się gubi, a wyzwanie stojące przed intelektem, czyli wychwycenie nieścisłości wypowiedzi może się okazać utrudnione. Największe trudności mogą się przy tym łączyć z taką formą wypowiedzi, która jest co prawda powierzchownie koherentna, lecz jednocześnie na tyle niezrozumiała, że na pierwszy rzut oka rodzi się wrażenie, iż zaniechanie dodatkowego wysiłku nie będzie tu miało wielkiego wpływu na zmianę sensu całości wypowiedzi. Jeśli natomiast zbyt skomplikowane są same słowa nadawcy wypowiedzi, może okazać się niezrozumiała i nie oddziałuje w przewidywany sposób.

Zależność między regułą przyczynowości, a mechanizmem konsekwencji. Zasada zgodności

Dążenie ludzkiego umysłu do tłumaczenia zjawisk za pomocą związku przyczynowo-skutkowego nie jest jedynie narzędziem instrumentalizacji fenomenów, służącym łatwiejszemu objęciu ich rozumem. Idea tego związku ma również określone znaczenie społeczne. Robert Cialdini określa pęd ku spełnieniu tej relacji zasadą zgodności.

Będąc podmiotami komunikacji, chcemy być postrzegani w oczach swych odbiorców jako osoby, których wypowiedź posiada wewnętrzną spójność. Bycie „człowiekiem o twardych zasadach” ma bowiem bardzo silny impakt

${ }^{4}$ M. Tokarz, Argumentacja, perswazja, manipulacja, Gdańskie Wydawnictwo Psychologiczne, Gdańsk 2006, s. 140. 
społeczny. Oczywiste jest przecież, że łatwiej ulega się wpływom osób, które się uznaje za rzetelne i twardo stojące przy swych przekonaniach. $Z$ drugiej strony, można powiedzieć, że osoby zachowujące się bardziej przewidywalnie będą wykazywały większy wpływ społeczny.

Przewidywalność jest zatem uznawana w społeczeństwie za cechę dość wysoko usytuowaną $\mathrm{w}$ hierarchii wartości ${ }^{5}$. Osoba konsekwentna postrzegana jest jako racjonalna, stabilna psychicznie, najogólniej zaś ujmując: godna zaufania. Ludzkie dążenie do uchwycenia świata w sidła logiki i logicznego myślenia jest niewątpliwe podstawą naszych przekonań o spójności charakteru człowieka w ogóle. To, co nie chce się poddać regułom logiki, jest nieprzewidywalne i wzbudza pewną awersję jako czynnik nie rządzący się żadnym określonym prawem.

Inną wartością tego typu jest bez wątpienia konsekwentność. Ułatwia komunikację, pozwala na bardziej ekonomiczne czasowo działanie i optymalizuje je, by uzyskiwać za każdym razem zadowalający sukces operacyjny.

Mając na uwadze pozytywne oraz negatywne strony zasady zgodności, warto dodać, że działanie człowieka, które nie jest idealnie wpasowane w nienaruszalne reguły logiczne, sprawia wrażenie działania przy pominięciu tej zasady. Często zdarza się też, że nie dokonujemy wyboru właściwego, lecz niezgodnego z wcześniejszymi decyzjami, gdyż ludzka potrzeba bycia uznanym za osobę konsekwentną przez innych jest silniejsza.

Nie znaczy to, że swe decyzje podejmujemy z wielką dozą ostrożności, ważąc wszystkie za i przeciw. Wiele $\mathrm{z}$ nich zapada w nas niejako automatycznie. W przypadku wytworzonych przez nas automatyzmów równie silna jest rola zasady zgodności. Skoro raz podejmiemy jakąś decyzję, dalej nie musimy jej już analizować. Pozwala to na luksus zmniejszenia zaangażowania sił mentalnych oraz umożliwia wykorzystanie tychże sił w innych celach. Cialdini ujmuje to w sposób następujący:

Zamiast tego wszystko, co musimy zrobić, gdy kwestia raz jeszcze przed nami stanie, to tylko zaktywizować naszą umysłową „taśmę” konsekwencji, klik, i już wiemy, co sądzić, mówić lub czynić $[\ldots]^{6}$.

Powyższy sposób przystosowania ludzkiego umysłu do odbioru dużych ilości informacji ze świata spowodowany jest tym, że świadomie trudno jest

${ }^{5}$ R. B. Cialdini, Wywieranie wpływu na ludzi. Teoria i praktyka, Gdańskie Wydawnictwo Psychologiczne, Gdańsk 2000, s. 41.

${ }^{6}$ Tamże, s. 70. 
nam objąć umysłem wszystkie elementy pakietów danych, jakie wychwytujemy z rzeczywistości. Samorzutnie pomijamy więc uznawane za zbędne detale, by działać w świecie skuteczniej i z mniejszym wysiłkiem. Jest to jeden z powodów, dla których czasem trudno nam nad tym procesem zapanować. Wygodniejsze wydaje się wówczas oddanie swoistemu automatyzmowi. Uznajemy, że raz podjęta decyzja uchrania nas od wysiłku skrupulatnej analizy czegoś, co już raz przecież zostało przeanalizowane.

Innym powodem, dla którego człowiek może unikać samodzielności myślenia jest obawa przed jego możliwymi wnioskami. Robert Cialdini przytacza tu następujący przykład: wraz ze znajomymi przyszedł kiedyś na kurs medytacji transcendentalnej i wziął udział w dyskusji z nią związanej. Jeden $\mathrm{z}$ jego znajomych podważył słabe punkty wypowiedzi prowadzących, wykazując wszelkie błędy w ich rozumowaniu, i tym samym unaocznił małą przydatność kursu. Jednakże uświadomienie zebranym tego faktu spowodowało zupełnie inny efekt niż można było się spodziewać. Wiele osób bezpośrednio po zakończonej dyskusji właśnie zapisało się na kurs i uiściło za niego opłatę. Gdy zapytano je o powody podjętej w tych okolicznościach decyzji, z ich odpowiedzi można było wywnioskować, że mimo dość dobrego zrozumienia argumentów przeciw przydatności kursu po prostu bardzo chcieli uwierzyć w jego przydatność. Początkowo zawierzyli słowom prowadzących, lecz gdy znajomy Cialdiniego przedstawił argumenty przeciw tej wierze, zapragnęli wyciszyć głos rozumu, pozostający tym samym w dającej komfort iluzji pewności. Uiszczając opłatę za kurs, aktywowali więc mechanizm wolicjonalnego zaangażowania. Ich rozumowanie zdawało się przebiegać wedle schematu: jeśli dokonało się inwestycji w jakąś sprawę, bardzo często będzie się przejawiało tendencję, by optować za nią, nawet niezależnie od tego, co mówi nasza racjonalność.

Manipulator z łatwością może wywołać pożądany skutek w wyobraźni osoby manipulowanej, jeśli tylko będzie wiedział, jak stopniowo budować zaangażowanie. Początkowo, stosując system pytań i odpowiedzi, wytwarza sytuację, w której odcinane są zbędne ścieżki zakłócające aplikację parametrów modyfikujących reakcję w przewidywany sposób. Im większy jest przy tym stopień zaangażowania manipulowanego, tym łatwiej będzie wymusić aktywację samorzutnej konsekwencji. Przykładowo: można niezobowiązująco zapytać kogoś, czy w pewnym całkowicie abstrakcyjnym przypadku, który jest $\mathrm{w}$ jakiś sposób odzwierciedleniem jego sytuacji, podjąłby się on określonego działania. Załóżmy, że osoba ta zgodzi się, zakładając brak konsekwencji działania. Owa powierzchowna wizja braku konsekwencji jest zaś tylko 
środkiem, by ostatecznie zamknąć manipulowanego właśnie w ich pułapce. Im lepiej zapoznamy się z rozmówcą (czyli im więcej informacji podamy manipulatorowi), w tym większym stopniu dostosuje się on do naszych personalnych wymogów. W tym konkretnym przypadku niezobowiązująca zgoda wiąże się jednak z ukrytym założeniem wypełnienia wcześniej stwierdzonej hipotetycznej akceptacji. Od tego momentu zaczyna działać zasada zgodności i manipulowany odczuwa potrzebę jej wypełnienia; im lepiej poznaliśmy osobę manipulującego, tym bardziej zależy nam na jego akceptacji.

Należy przy tym zwrócić uwagę na kwestię siły pytania, ponieważ to właśnie taka forma wypowiedzi najskuteczniej angażuję osobę manipulowaną w rozmowę, co znacząco ułatwia aplikację struktur manipulujących. To stopniowe zadawanie pytań, wciągające $\mathrm{w}$ sferę manipulacji nazywane jest „techniką stopy w drzwiach". Często stosują ją na przykład sprzedawcy próbujący nakłonić kupujących do zakupu czegoś mało wartościowego, co w konsekwencji pociąga za sobą kolejne zakupy.

Operując na potrzebach i oczekiwaniach innych, manipulator jest w stanie doprowadzić do sytuacji, w której za osiągnięte skutki zostanie wręcz pochwalony i nagrodzony. Skuteczność manipulacji jest oczywiście zależna od stopnia szczegółowości informacji, które ofiara manipulatorowi przekazuje, choć oczywiście w kręgu manipulacji, z którego nie ma już ucieczki, może umieścić ofiarę nawet zgoda na niewielką przysługę czy odpowiedź na drobne pytanie.

Wywoływanie zaangażowania jako przyczyna podtrzymywania mechanizmów konsekwencji oraz „ochrona przed myśleniem”. Manipulacja obrazem osoby

Zaangażowanie jest mechanizmem, który w miarę wystawiania go na próbę czasu w niesprzyjających warunkach traci swoją skuteczność. Jednakże umiejętne wykorzystanie technik podobnych do techniki „stopy w drzwiach” pozwala na rozpoczęcie $\mathrm{w}$ osobie manipulowanej permanentnych zmian. Dzieje się tak, gdyż decyzję o zaangażowaniu osoba ta podjęła samodzielnie. Co sprawia, że czuje się ona odpowiedzialna za całą zaistniałą sytuację psychologiczną. To poczucie odpowiedzialności wystawia na próbę obraz osoby, zarówno w jej własnych oczach, jak i w domniemanym spojrzeniu innych. Każdy z nas bardzo zaś chce utrzymać konsekwentny charakter obrazu swojej osoby często za wszelką cenę. Długoterminowość efektów manipulacji obrazem osoby ma więc poniekąd swe źródło w nas samych. Jeśli parametr 
zmieniający model postępowania osoby zostanie poprawnie i dostatecznie skutecznie zaimplementowany, $\mathrm{w}$ postrzeganiu przez manipulowanego samego siebie następuje zmiana. Co więcej, im większe i bardziej długotrwałe zaangażowanie $\mathrm{w}$ decyzję danej osoby, tym silniejsze okażą się efekty tego działania. W momencie dostrzeżenia, że we własnym obrazie tej osoby rozpoczęły się zmiany, manipulator stara się aktywować wiele środków, które będą miały uwiarygodnić fakt, że dzieje się to $\mathrm{w}$ wyniku podjętych przez tę osobę autonomicznych decyzji. Następnie będzie starał się wpleść ją w szereg kolejnych tego typu „decyzji”, uwierzytelniając nowy, niepasujący element do następnych i pozornie utrzymując zasadę zgodności. W efekcie ofiara zwykle sama chce wierzyć w to, że jej czyn został dokonany autonomicznie, bez żadnego zewnętrznego wpływu. Tu leży przyczyna faktu, że proces manipulacji widoczny jest w sposób oczywisty dla osoby trzeciej, będącej jedynie biernym świadkiem. Dla osoby będącej obiektem owego procesu, uświadomienie sobie, że staje się jego ofiarą jest o wiele trudniejsze. Wynika to między innymi stąd, że na osobę, której tok myślenia pozostaje wewnątrz modelu działa parametr określony przez wiele adekwatnych do sytuacji zmiennych. Ów parametr zmienia się przy tym dynamicznie, zależnie od informacji podawanych przez manipulowanego. Czyni to ewentualne wydostanie się z pułapki zadaniem bardzo trudnym, gdyż sama pułapka w specyficzny sposób przystosowuje się do cech kogoś, kto ma w nią wpaść.

Manipulacja obrazem osoby w połączeniu z początkowo sztucznie wywołanym, a następnie samodzielnie podtrzymywanym przez manipulowanego zaangażowaniem potrafi wpłynąć na wiele elementów jego ekspresji. W przypadku, gdy zmienia się czyjś punkt widzenia w konkretnej sprawie, pociąga to za sobą zmiany w zachowaniu oraz postrzeganiu innych rzeczy, osób, sytuacji. Przykładem mogą być koreańscy jeńcy wojenni schwytani przez Chińską Armię Ludowo-Wyzwoleńczą:

I nagle jeniec taki budził się jako pomagający wrogowi „kolaborant”. Świadom tego, że napisał swoje wypracowanie w gruncie rzeczy bez wyraźnego przymusu czy gróźb, człowiek taki nieraz zmieniał obraz siebie samego we własnych oczach tak, aby uwzględnić ten postępek i etykietkę „kolaboranta”, co często prowadziło do jeszcze dalej idącej kolaboracji?

W miarę postępu procesu manipulowania takie praktyki mogą sięgnąć poziomu, gdzie dochodzi do sytuacji, w której dany żołnierz opuszczający

7 Tamże, s. 79. 
obóz sam staje się zatwardziałym wyznawcą ideologii wrogiej armii. Kluczem do tak silnych efektów nie jest bynajmniej zmienianie danej osoby, lecz wytworzenie warunków, w których ona sama dokona większości zmian. Zabieg o takim charakterze jest o wiele trudniejszy do wykrycia. Im dłużej trwa okres podtrzymywania poczucia własnej konsekwencji po dokonaniu zmiany w obrazie siebie, tym trudniej dostrzec drobny detal, który wprawił w ruch działanie całego modelu manipulacji.

\section{Korzenie społecznego dowodu słuszności oraz problemu tzw. „małpowania”" według różnych psychologów}

Zachowanie człowieka w określonej sytuacji nadzwyczaj często determinowane jest przez zachowanie innych ludzi. Najlepiej obrazuje to społeczny dowód słuszności. Człowiekowi łatwiej jest przyjąć pewne zachowanie za słuszne, gdy widzi, że inni też tak się zachowują. Im więcej osób przyzwala na pewien sposób zachowania, tym bardziej wydaje się on właściwy. Jest to ważna zależność, gdyż operowanie nią stanowi bardzo skuteczny sposób manipulacji. W sytuacji, gdy jakiś model używany jest do manipulowania wyobraźnią pojawia się możliwość wykorzystania mechanizmu społecznego jako dowodu słuszności w celu pośredniego zwiększenia siły oddziaływania parametrów wpływających na osobę manipulowaną. W takiej sytuacji niezbędnym elementem staje się wywołanie w wyobraźni ofiary stanu niepewności. Może on mieć swe źródło w dwuznaczności wypowiedzi, niejasności kontekstu czy w wystawieniu pewności jakiegoś konkretnego zachowania w określonej sytuacji na próbę poprzez szczegółowe pytania i silną kontrargumentację. Manipulowany swoim zachowaniem daje zwykle po sobie poznać, czy podejmując ostateczną decyzję w kwestii tego, co powinien uczynić, będzie opierał się na działaniach innych osób. Oczywiście obserwowanie innych w poszukiwaniu potwierdzenia swych własnych czynów zazwyczaj bywa bardzo zdawkowe, bo tak naprawdę nikt nie chce dać po sobie poznać, że w swym osądzie opiera się na takim potwierdzeniu. Mimo to, odpowied-

\footnotetext{
${ }^{8}$ W aspekcie psychologicznym „małpowanie” kojarzy się z dolegliwością manieryzmu. Kant określa to w następujący sposób: „Manieryzm jest innym rodzajem małpowania, a mianowicie samej tylko osobliwości (oryginalności) w ogóle, aby jak najbardziej oddalić się od naśladowców, nie posiadając przecież talentu, by być zarazem czymś, co służy za wzór". (I. Kant, Krytyka władzy sądzenia, przeł. J. Gałecki, Warszawa 1964, s. 249-250).
} 
nie wyćwiczenie w zakresie wychwytywania zachowań wskazujących na niepewność oraz potrzebę walidacji jest jednak możliwe.

Bezpośredni kontakt z osobami, których poglądy lub zachowanie są w stanie zapewnić manipulowanego o słuszności jego własnej postawy, jest bodźcem bardzo silnym, lecz oddziaływanie takowego bodźca nie zawsze bywa jednorodne. Podając świadectwa innych, dotyczących trafności moich działań, czy też odwołując się do zakamuflowanych sposobów przekazu informacji o wzorcach zachowań również mogę ulegać silnej sugestii. Jeśli dodatkowo manipulator pamięta o wykorzystaniu zdawkowego przekazywania informacji o biernym charakterze, sprawiając, że manipulowany ma wrażenie, iż to on samodzielnie odkrywa daną zgodność lub sposób zachowania. Mechanizmy zmieniające decyzje osoby pozostającej w obrębie oddziaływania modelu stają się tym bardziej skuteczne.

Niepewność i potrzeba walidacji swoich zachowań u innych może też zostać wykorzystana w jeszcze inny sposób. Należy pamiętać o tym, że ludzie zarówno wewnątrz modelu manipulacji, jak i w wielu życiowych sytuacjach poszukują zewnętrznych wzorców zachowań. Daje to możliwość pogłębienia poczucia niepewności u osoby manipulowanej poprzez częściowe rozszerzenie modelu manipulacji na inne osoby, które w danej chwili również wykazują niepewność. Umiejętna modyfikacja modelu, która zachowuje swój dyskretny charakter będzie starała się utrzymać pozostałe osoby wewnątrz zakresu swego oddziaływania tylko przez niezbędną ilość czasu. W momencie, gdy ich rola zostanie spełniona, manipulator będzie starał się znów oddzielić manipulowanego od wszelkich zewnętrznych osób, które łatwiej mogłyby dostrzec proces manipulacji.

Wykorzystanie niepewności na szerszą skalę może doprowadzić do sytuacji, w której wytworzy się tak zwana niewiedza wielu (pluralistic ignorance). Istota tego fenomenu psychologicznego da się wyjaśnić następująco: jeśli na przykład widzimy na ulicy osobę poszkodowaną, jednocześnie zaś nie będzie $\mathrm{w}$ pobliżu człowieka poczuwającego się do podjęcia działań ratowniczych, może zdarzyć się, że pomoc nie zostanie udzielona. Wedle relacji osób, które były w podobnej sytuacji, nie były one w stanie znaleźć argumentów usprawiedliwiających ich bierność. Ktoś obserwujący całe zdarzenie mógłby nawet bez ponoszenia jakichkolwiek konsekwencji, przy bardzo małym wysiłku pomóc bliźniemu w nieszczęściu, jednakże stawało się to swoistą przyczyną pasywności. Im więcej osób jest przy tym częścią grupy podatną na mechanizm niewiedzy wielu, tym bardziej zmniejsza się osobista odpowiedzialność za to, co ostatecznie zaszło. Znikome zaangażowanie innych stanie się sugestią do 
podobnego zachowania każdej dołączającej do grupy osoby. Kolejnym czynnikiem wzmacniającym poczucie pewności staje się możliwość odniesienia własnego wizerunku do wizerunku innej osoby. Jeśli inny wykazuje podobne do moich cechy, łatwiej jest mi wyobrazić sobie samego siebie w sytuacji, w jakiej on się znajduje.

Nie oznacza to, że stan niepewności, gdy idzie o orientację w sytuacji zawsze musi być stanem negatywnym. Często wynika on po prostu $\mathrm{z}$ braku wiedzy czy, by uciec się do podanych wcześniej przykładów, dana osoba faktycznie potrzebuje pomocy, zakup konkretnego urządzenia jest właściwy lub też człowiek ma rzeczywiście względem nas takie zamiary, jakie deklaruje. Zwłaszcza, gdy nie jesteśmy ekspertami w danej dziedzinie, warto przy podejmowaniu decyzji zwrócić się ku osobom mającym większe doświadczenie, kopiując ich zachowanie oraz decyzje. Może się to przyczynić do większego operacyjnego sukcesu naszych działań. Ponadto te same sytuacje mogą być w różnych miejscach lepiej bądź gorzej zrozumiane. Odwołujmy się tu do przykładu człowieka leżącego na ziemi w bezruchu w centrum miasta. Można wyobrazić sobie wiele pozbawionych konieczności interwencji powodów, dla których przyjął on taką pozycję, ale gdy ta sama sytuacja wydarzy się na skraju lasu prawdopodobieństwo, że potrzebuje on pomocy jest o wiele większe. Dla każdego manipulatora bardzo istotnym czynnikiem jest znajomość otoczenia. Dzięki niej wie on, które elementy z sytuacji powinny stać się częścią modelu, a które mogą jego wysiłki zniweczyć. Po odpowiednim zapoznaniu się z miejscem, gdzie będzie aplikowany model manipulacji, można przystąpić do umiejscowienia osoby manipulowanej w środowisku, nad którym ma się dużą kontrolę. Można powiedzieć, że przez właściwą kontrolę otoczenia osiąga on konkretny rodzaj kontroli nad tym, kim manipuluje. Stwarza to wrażenie, że w pewien sposób „przyzwala” na to, by wszystkie elementy zadziałały we właściwym momencie i z przewidzianym skutkiem.

Obrona przed manipulacją przy wykorzystaniu społecznego dowodu słuszności. Analiza osoby manipulującej

Chcąc się zabezpieczyć przed nadużywaniem mechanizmu konsekwencji i zaangażowania, należy pamiętać, że choć pewne automatyzmy są w życiu codziennym przydatne, to zawsze podleganiu im musi towarzyszyć pytanie, czy taka „droga na skróty” w tym konkretnym wypadku jest wskazana. 
Robert Cialdini wskazuje na pewne rodzaje sygnałów i metod ostrzegawczych, mogących świadczyć o możliwości bycia manipulowanym. Na pierwszym miejscu należy tu wymienić zrozumienie, że jeśli rozmówca stara się nas złapać w pułapkę naszej konsekwencji, którą rzekomo możemy zaburzyć, zaczynamy odczuwać swoisty dyskomfort psychiczny utrudniający nam ostateczne podjęcie decyzji. Powód powstania tych blokad mentalnych można tłumaczyć brakiem samodzielnego zrozumienia sytuacji, a następnie podjęcia w niej autonomicznej decyzji. Manipulator wywiera presję na logiczną stronę myślenia manipulowanego, stawiając go przed alternatywą: albo będę konsekwentny, albo dosięgną mnie pewne nieskonkretyzowane sankcje społeczne będące skutkiem przypisania mi opinii osoby niekonsekwentnej. Jeśli zdecyduję się wziąć na siebie brzemię osoby niekonsekwentnej, to mimo, że zmniejszy się moja wiarygodność w oczach innych, stanę się bardziej odporny na zabiegi manipulatora, dla którego w rzeczywistości zagadnienie, jak konsekwentna jest jego potencjalna ofiara, nie jest przecież zbyt istotne. Może też się zdarzyć, że moje nieprzewidziane w modelu działanie unaoczni otoczeniu, że cała sytuacja zainscenizowana została nie po to, by wykazać niekonsekwencję ofiary lub obalić jej stanowisko, lecz po to, by tę ofiarę wykorzystać. Zawsze istnieje też możliwość wytłumaczenia wszystkim osobom funkcjonującym w granicach modelu, w tym manipulatorowi, co ten ostatni chce osiągnąć i w jaki sposób do tego dąży. Takie demaskowanie stanowi jeden ze skuteczniejszych sposobów radzenia sobie z osobami manipulującymi.

Powyższy sposób obrony przed manipulacją ma jednak swoje ograniczenia. Osoba manipulowana, po to, by wyczuć, że ktoś nią steruje, musi działać w modelu manipulacji, a tu mechanizm obrony może czasem zadziałać za późno. Innym mankamentem jest tu fakt, że jeśli człowiek stara się przekonać samego siebie, iż jego sterowane z zewnątrz działanie jest słuszne i co stanowi warunek funkcjonowania w granicach modelu, świadomość znajdowania się $\mathrm{w}$ pułapce konsekwencji może nie pojawić się $\mathrm{w}$ ogóle. Chcąc pomóc takiemu komuś, kto sam zamyka się w błędnym kole swego nieracjonalnego myślenia, lecz konsekwentnego działania, najlepiej odwołać się do tej części naszego umysłu, dla której niedorzeczność tego typu decyzji jest jednak oczywista. Bardzo często pierwsze wrażenie, jakiego doświadczamy w obliczu jakiejś rzeczy lub procesu, jest wrażeniem, gdy idzie o późniejszy tok myślenia, decydującym według badań przeprowadzonych w latach osiemdziesiątych ubiegłego stulecia; rzeczywistość najpierw odbieramy sferą emocji, a dopiero później intelektem. Dominacja tego pierwsze- 
go sposobu odbioru łatwo może nas przywieść do błędu, którego uniknięcie staje się łatwiejsze po zastosowaniu odpowiedniego treningu, pomagającego odróżnić zdania emocjonalne od konstruktów logicznych.

Doskonałym sposobem radzenia sobie z manipulacją jest introspekcja. Oprócz umiejętności wychwytywania doświadczenia czystych emocji, warto obserwować wewnętrzny obraz samych siebie. Jeśli sytuacja wymaga od nas wprowadzenia zmian w obrazie lub zmusza nas do jego dookreślenia, istnieje duża szansa, że dzieje się tak za sprawą aplikacji parametrów, które mają za zadanie tak zmodyfikować obraz, by późniejsze działania lub automatyzmy funkcjonowały w danym modelu tak, jak przewidziała to osoba manipulująca.

Tak jak nie istnieje jeden uniwersalny sposób manipulacji, tak nie istnieją niezawodne metody obrony przed nią. W tej ostatniej kwestii wszystko zależy od warunków, w jakich następuje aplikacja modelu, od tego z jak skomplikowanych sposobów korzysta manipulator, jakie metody obrony zna potencjalna ofiara i na ile umiejętnie je wykorzystuje. Każda sytuacja, mimo pewnej dozy schematyczności, zawsze będzie inna i będzie wymagać innych działań od obu stron. Istnieje za to jeden niezawodny sposób, by zawsze zwiększyć stopień ochrony przed manipulacją - poznać wiedzę na temat sposobów wykorzystywanych przez manipulatorów do sterowania innymi. Dlatego to sam manipulator nierzadko może okazać się najlepiej przygotowanym do obrony.

Odwołując się do zasad logiki oraz ustaleń psychologii, jesteśmy w stanie zrozumieć dwie sfery manipulacji. Elementem spajającym je staje się sam model, w którym ujawnia się natura tego rodzaju działań. Żeby więc lepiej zrozumieć istotę manipulacji oraz zdobyć wiedzę, jak się przed nią ustrzec, należy znać zarówno używane w jej trakcie metody, jak i rządzące tymi metodami zasady.

\section{Bibliografia}

Arystoteles, Organon III - Prior Analytics, [w:] Aristotle - Works, red. W. D. Ross, Constitution Society, URL=<http://www.constitution.org/ari/aristotle-organon + physics.pdf>

Cialdini R. B., Wywieranie wptywu na ludzi. Teoria i praktyka, Gdańskie Wydawnictwo Psychologiczne, Gdańsk 2000.

Papineau D., The Insignificance of Woodward's Manipulations, Sydney 2009. 
Tokarz M., Argumentacja, perswazja, manipulacja, Gdańskie Wydawnictwo Psychologiczne, Gdańsk 2006.

Woodward J., Making things happen, Oxford University Press, New York 2003.

Woodward J., Causation and Manipulability, The Stanford Encyclopedia of Philosophy, Edward N. Zalta (ed.), URL $=<$ http://plato.stanford.edu/entries/causationmani/>

\begin{abstract}
Comprehensive Outline of J. Woodward's Causal Theory of Manipulation

Manipulation is a phenomenon examined from perspectives of various scientific disciplines. Applying logic and the knowledge about different sociotechniques can become a way to better understanding of this phenomenon. By analyzing goaloriented actions within social situations as models of influence that are based on probability and dynamic adaptation to various variable conditions can become a successful method for more thorough research within human societies.
\end{abstract}

Key words: manipulation, sociotechnique, logic, society, manipulation model, consistency, adaptation 